\title{
Management of Diffuse Abdominal Cellulitis After Cesarean Section
}

\section{Sezaryen Sonrası Gelişmiş Yaygın Karın Selüliti Olgusu Yönetimi}

\author{
(D) Sümeyra Nergiz Avcıoğlu, (D) Emre Zafer, (D) Sündüz Özlem Altınkaya, (D) Selda Demircan Sezer, (D) Hasan Yüksel \\ Aydın Adnan Menderes University Faculty of Medicine, Department of Obstetrics and Gynecology, Aydın, Turkey
}

Keywords

Cesarean section, cellulitis, debridement

Anahtar Kelimeler

Sezaryen, selülit, debridman

Received/Geliş Tarihi : 19.08.2015

Accepted/Kabul Tarihi : 23.11.2015

doi:10.4274/meandros.galenos.2015.2456

Address for Correspondence/Yazışma Adresi: Sümeyra Nergiz Avcıŏlu MD,

Aydın Adnan Menderes University Faculty of Medicine, Department of Obstetrics and Gynecology, Aydın, Turkey

Phone : +90 2562112871

E-mail : sumeyranergiz80@gmail.com ORCID ID: orcid.org/

(C) Meandros Medical and Dental Journal, Published by Galenos Publishing House.

This is article distributed under the terms of the

Creative Commons Attribution NonCommercial 4.0

International Licence (CC BY-NC 4.0).

\begin{abstract}
In present case report, diffuse abdominal cellulitis is discussed under light of data in literature. Thirty-nine years old patients refered to our clinic, with the cesarean wound dehiscence and diffuse abdominal erythema, pain, increased temperature at 6 th day of cesarean section. Initial diagnosis was diffuse abdominal cellulitis after cesarean section. In spite of antibiotic treatment and drainage, clinic of patient did not regress. So, a transverse insicision at left lumbar area near to midline and below umblicus was performed and phannenstiel insicion was extended upwards to right side under general anestesia. Drainage and debridement was performed. Between two insicions, skin and subcutaneous tissues were left as a bridge and tissue above the fascia was under arch of bridge. Necrotic tissues was excised. The insicions at abdominal area, were expected to heal secondarily. When the clinic and symptoms of patient was improved, at postoperative $36^{\text {th }}$ day, she was discharged with daily wound dressing and control. In conclusion, serious superficial and subcutaneus tissue infections developed after cesarean section should be taken into intensive care and treatment protocols. Besides, these cases should be under observation due to increased risk of sepsis.
\end{abstract}

Öz

$\mathrm{Bu}$ olgu sunumunda sezaryen sonrası gelişen ciddi karın duvarı selüliti olgusu literatür bilgileri eşliğinde tartışılmıştır. Otuz dokuz yaşında hasta sezaryen sonrası postoperatif 6 . günde yara yeri açılması ve karın cildinde yaygın eritem, ağrı ve ISı artışı şikayeti ile refere edildi. Sezaryen sonrası gelişen karın duvarı selüliti düşünüldü. Antibiyotik tedavisi ve drenaja rağmen kliniği düzelmeyen hastaya, genel anestezi altında umbilikus sol lumbar bölgenin orta hattı geçen yakın yerinden transvers kesi uygulandı ve pfannenstiel kesisi sağa yukarıya doğru uzatıldı. Drenaj ve debridman yapıldı. İki kesi arasında köprü olarak deri ve deri altı enfekte yapılar bırakıldı, fasyanın üstü köprüaltı boşluk olarak kaldı. Nekrotik alanlar cerrahi olarak çıkarıldı. Mevcut açık yaralar sekonder iyileşmeye bırakıldı. Postoperatif 36. günde klinik durumunun düzelmesi üzerine hasta günlük kontrol ve pansumanlara çağrılmak üzere taburcu edildi. Sonuç olarak, sezaryen sonrası gelişen ciddi yüzeyel deri ve deri altı doku enfeksiyon olguları yoğun bir izlem ve tedavi protokolüne alınmalı, bu hastaların sepsise ilerleme riskleri bakımından gözlem altında tutulmalıdırlar. 


\section{Introduction}

Cellulitis is an infection involving the dermis and the subdermis, having a sudden onset and spreading quickly. Cesarean section is one most frequently performed surgeries in the United States and Turkey. The rate of surgical site infections in clean surgeries like cesarean section is lower than $2 \%$ (1). The causative agents are usually Streptococcus pyogenes and Staphylococcus aureus. Traumatized regions, surgical sites and eczema and chicken pox lesions, where the skin integrity is disrupted, can be the ports of infections; however, in some cases there can be no ports of infections (2). Although cellulitis rarely appears after cesarean section, it causes very severe morbidity when it occurs. In this report, a case of diffuse abdominal cellulitis will be discussed.

\section{Case Report}

A 39-year-old Gravida 3 and Parity 2 with 38-week-gestation underwent cesarean section for non-progressive labor in a health care center. Upon detection of surgical wound dehiscence, diffuse abdominal erythema and increased local temperature during removal of the surgical sutures, the patient was referred to our clinic. When the patient was presented to our clinic, her body temperature was $36.7{ }^{\circ} \mathrm{C}$, her heart beat was $88 / \mathrm{min}$, her respiratory rate was $22 / \mathrm{min}$ and her blood pressure was $100 / 80$ $\mathrm{mmHg}$. On physical examination, Pfannenstiel suture line was open and had necrosis and odor. Abundant purulent discharge was observed in the subdermis, suggestive of a surgical site infection. On inspection, the skin extending to the umbilicus was painful and hyperemic. The skin in the epigastric region $4 \mathrm{~cm}$ above the umbilicus was necrotic and gangrenous. Ultrasonography performed in our clinic and in the center where the patient had cesarean section did not show a remarkable feature, but revealed thickness and increased echogenicity and linear fluid, suggestive of abdominal free fluid and edema in the anterior abdominal wall. Hemoglobin was $10.9 \mathrm{~g} / \mathrm{dL}$, white cell count was $18.5(\times 109 / \mathrm{L})$ and C-reactive protein: 71 $\mathrm{mg} / \mathrm{L}$. Surgical site culture was obtained. The patient was diagnosed as superficial skin infection initially and administered cefazolin sodium (sefozin, Bilim ilaç, İstanbul, Turkey) $2 \mathrm{~g}$ four times a day intravenously. Drainage tubes were placed in the subdermis and on the fascia in the surgical incision area and in the left paramedian region for evacuation and irrigation of the dermis and subdermis collection extending towards the umbilicus. Two days after initiation of this treatment, it was replaced by ampicillin-sulbactam (Duocid, Pfizer İlaç, İstanbul, Turkey) $1.5 \mathrm{~g}$ four times daily through the intravenous route.

On the postoperative eighth day, the wound site was irrigated when the patient was under general anesthesia. When the drainage was insufficient, a transverse incision under the umbilicus $12 \mathrm{~cm}$ in length and starting from the left lumbar area was made and the Pfannenstiel incision was lengthened $5 \mathrm{~cm}$ both on the right and on the left (Figure 1).

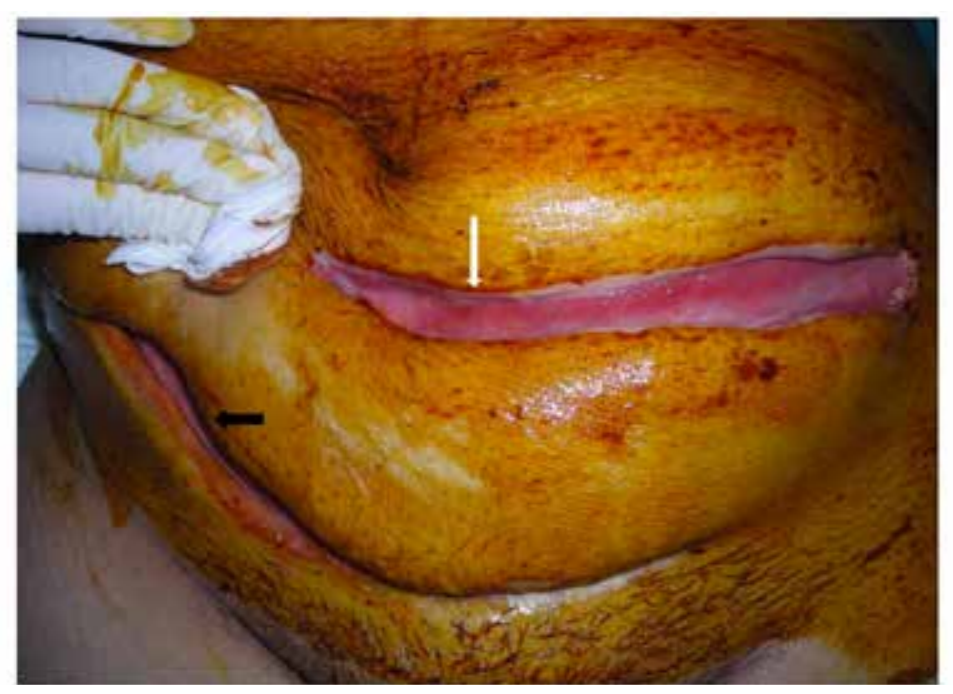

Figure 1. Transverse incision extending through the inferior part of the umbilicus and close to the midline of the left lumbar region (white arrow) and pfannenstiel incision extending to the right superior part (black arrow) 
Drainage, irrigation, aspiration and debridement were performed. Between the two incisions were dermal and subdermal infected tissues left as a bridge. Necrotic areas were surgically removed. Two drainage tubes were placed in the subdermis; one through the Pfannenstiel incision and the other through the transverse incision in the left lumbar region. Aspiration and irrigation were performed through these tubes three times a day. The wound culture obtained on admission to our clinic showed staphylococcus aureus (sensitive to ampicillin/sulbactam); therefore, the treatment initiated on admission was continued. When the patient's temperature increased, blood, urine and throat cultures were obtained, but they did not show bacterial growth.

On the postoperative $13^{\text {th }}$ day, the tissues under the Pfannenstiel incision towards the umbilicus were explored under general anesthesia. The fascia was intact. The drainage tubes placed in the incision sites were removed. Necrotic, purulent and infected tissues in the incision and debridement areas were excised. Obtained specimens were sent to the microbiological laboratory and no bacterial growth was detected. Debrided areas were first irrigated with $\mathrm{NaCl}$ solution and then with diluted batticon and rifocine. Debrided areas were left open and the rest was closed with wet tampons. When hemoglobin was found to be $7.6(\mathrm{~g} / \mathrm{dL})$, the patient was given three units of blood and two units of fresh frozen plasma. After these infusions, hemoglobin increased to $11.2(\mathrm{~g} / \mathrm{dL})$. After debridement, we continued to perform wound dressing three times a day. On the postoperative $17^{\text {th }}$ day, clinical improvement started. The wounds were left to have secondary healing. Upon complete clinical improvement on the postoperative $36^{\text {th }}$ day, the patient was discharged and instructed to come to hospital for daily wound dressing and other controls.

\section{Discussion}

Cellulitis is an acute infection involving the subdermis and subcutaneous fat tissue. It typically presents with tenderness, pain and erythema. The margins of the lesion on the skin were unclear. Local lymphadenopathy (LAP) and lymphangitis were common. Local abscesses and necrosis may appear (1). The case reported here presented with wound dehiscence and diffuse erythema. She also had necrotic, gangrenous skin $4 \mathrm{~cm}$ above the umbilicus in the epigastric region, but did not have LAP.

In most of the obstetric cases, surgical site infections are not life-threatening (1). However, as cellulitis has the risk of spread through lymphatics, it is a serious infection. It can develop both on the basis of traumas (grazes and incisions), surgical wounds and skin lesions and on the intact skin through the hematogenous route. It can rarely develop due to an underlying infection focus (osteomyelitis and abscess). It can appear in the late postoperative period, especially on the postoperative fourth day (2). In the case reported here, it appeared on Pfannenstiel incision on the postoperative sixth day after cesarean section.

The factors predisposing to cellulitis are obesity, cutaneous lesions, venous insufficiency and lymphatic obstruction, immunosuppression, diabetes, chronic diseases, drugs (corticosteroids), malnutrition, age of $>60$, intravenous administrations of drugs and vascular diseases (3). In the case presented here, there was not a risk factor except for cesarean.

In severe cases of cellulitis, fever, tachycardia, confusion and hypotension may develop together with bacteremia. Polymorphonuclear leukocytosis can be seen. Although petechia and ecchymosis are expected to appear, necrotizing fasciitis should be ruled out when they are diffuse and accompanied by systemic toxicity (4). The case presented here had fever, tachycardia and polymorphonuclear leukocytosis, but did not have hypotension, confusion or ecchymosis. In addition, the fascia was intact initially and throughout the course of the disease.

Indications for hospitalization of cellulitis cases are rapid progression of the disease, asplenia, neutropenia, immunocompromised patients, cirrhosis and cardiac-renal failure. The present case was hospitalized due to wound dehiscence and the rapid progression of the infection. Consistent with the literature (2), wound culture and blood culture were obtained and Staphylococcus aureus was isolated from the wound culture.

In patients with cellulitis having an indication for hospitalization, first antibiotics should be given parenterally. When the disease is kept under 
control clinically, antibiotics should be given orally (5). Community based cellulitis cases can be given cefazolin (4x $1.0 \mathrm{~g}$ intravenously), cefadroxil (1-2 x1.0 $\mathrm{g}$ orally), cefalexin, clindamycin or erythromycin. Ampicillin-sulbactam (4x $1-3 \mathrm{~g} /$ day intravenously) are the treatment of choice in cellulitis caused by resistant strains. Methicillin resistant Staphylococcus strains can be treated with linezolid (zyvoxid 2x $0.6 \mathrm{~g}$ intravenously or orally) or glycopeptides (teicoplanin $1 \times 400 \mathrm{mg} /$ day intravenously and vancomycin $4 \times 500$ $\mathrm{mg} /$ day intravenously). Treatment should last 14 days $(3,4)$. The case presented here was first diagnosed as superficial skin infection and instituted cefazolin as recommended by the infectious diseases department; however, upon isolation of Staphylococcus aureus on wound culture (sensitive to ampicillin/sulbactam), the treatment was replaced by ampicillin-sulbactam.

Another clinically important point is whether there is a superficial necrotic area in the first lesion. It should be kept in mind that infection can be caused by methicillin resistant Staphylococcus aureus in cases having necrotic crust. The exotoxin released by Staphylococcus aureus causes severe necrosis in the area where it is secreted. Necrotic skin lesions can create necrotizing pneumonia and deep tissue abscesses. Therefore, a mechanical approach in addition to appropriate antibiotics should be used in patients having necrotic lesions. The infected area above the fascia should be opened and the margins of the wound should be removed and debrided. Wound care and dressing should be performed two or three times daily. This helps formation of granulation tissue and closure of the wound secondarily (3-5). In the case reported here, a large debridement of the wound was carried out under general anesthesia. An incision parallel with the superior part of the wound was made. Our primary aim was to prevent development of an infection involving the fascia. It would have been difficult to evaluate the fascia left under the infection in a vertical incision. In addition, it would not have been possible to prevent spread of the infection to the fascia. However, we left the non-necrotic infected dermal and subdermal tissues. By leaving the dermal and subdermal tissue and thus creating a bridge, we aimed to facilitate secondary healing of the nonnecrotic tissues. If we had removed these tissues completely, there would have been a large dermal and subdermal defect and a problem with healing. We even would have had to create a flap for a large area.

In conclusion, some simple preventive strategies like asepsis in the preoperative incision area, adoption of surgical principles and prophylactic use of systemic antibiotics can reduce the incidence of postsurgical infection $(1,6)$. In addition, cleaning the surgical site with chlorhexidine 24 hours before surgery has been shown to decrease the risk of infection $(7,8)$. Despite all these precautions, infectious morbidity is an inevitable complication of surgery. In cases having diffuse abdominal cellulitis, similar to the one reported here, treatment with antibiotics and mechanical debridement in resistant cases can prevent progression of the clinical picture to complications like necrotizing fasciitis or sepsis.

Presented Congress: $7^{\text {th }}$ National Gynecology and Obstetrics Congress, Kyrenia, Girne, KKTC, 14/05/2009.

\section{Ethics}

Informed Consent: Consent form was filled out by all participants.

Peer-review: Externally and internally peerreviewed.

\section{Authorship Contributions}

Surgical and Medical Practice: H.Y.Ü., S.N.A., Concept: S.D.S., Design: E.Z., Data Collection or processing: S.N.A., Analysis or Interpretation: H.Y., S.Ö.A., Literature Search: E.Z., Writing: S.N.A.

Conflict of Interest: No conflict of interest was declared by the authors.

Financial Disclosure: The authors declared that this study received no financial support.

\section{References}

1. Kaimal AJ, Zlatnik MG, Cheng YW, Thiet MP, Connatty E, Creedy $P$ et al. Effect of a change in policy regarding the timing of prophylactic antibiotics on the rate of postcesarean delivery surgical-site infections. Am J Obstet Gynecol 2008; 199: 310.e1-5.

2. Hirshmann JV. Fungal, bacterial, and viral Infections of the skin: Bacterial infections. ACP Medicine Online 2002.

3. Daum RS. Skin and soft-tissue infections caused by methicillinresistant staphylococcus aureus. N Engl J Med 2007; 357 :38090.

4. Pong AL, Bradley JS. Guidelines for the selection of antibacterial therapy in children. Pediatr Clin N Am 2005; 52: 869-94.

5. Staphylococcal infections. In: Pickering LK, Baker CJ, Long SS, Mc Millian JA, eds. Red Book 2006: Report of the committee on infectious diseases. 27th ed. Elk Grove Village, IL: American Academy of Pediatrics; 2006; 598-629. 
6. Smaill F, Hofmeyr GJ. Antibiotic prophylaxis for cesarean section Cochrane Database Syst Rev. 2002; CD000933.

7. Hadiati DR, Hakimi M, Nurdiati DS, Ota E. Skin preparation for preventing infection following caesarean section. Cochrane Database Syst Rev 2014 Sep 17; 9: CD007462.
8. Mpogoro JF, Mshana SE, Mirambo MM, Kidenya BR, Gumodoka $B$, Imirzalioglu C. Incidence and predictors of surgical site infections following caesarean sections at Bugando Medical Centre, Mwanza, Tanzania. Antimicrob Resist Infect Control 2014; 11: 25. 